\title{
O Amor - segundo Clarice Lispector
}

\author{
Love - according to Clarice Lispector
}

\author{
José PAUlO CRUZ PEREIRA
}

Universidade do Algarve - Algarve - Portugal

\begin{abstract}
Resumo: Em “Amor", de Clarice Lispector, lemos a forma como a vida e a escrita se cruzam, enquanto modalidades de um encontro com o Outro no qual se suspendem os limites que separam a lei da exceção, o saber da alteridade, o real da ficção. A sua premissa é a de uma cegueira concebida como experiência, não apenas da insularidade e do aban-dono, do sepultamento vivo - tal como ela é frequentemente pensada na tradição literária do Ocidente: "eu próprio o meu sepulcro, o meu túmulo, enterrado...", diz John Milton, no seu Samson Agonistes - mas também, como em "Amor", da alteridade e da transcendência, na indecisão limítrofe que marca toda a relação imaginária. Em Água viva, essa "cegueira" expressa-se pelo sentido de um "figurativo do inominável”. Em “Amor” é assumida na relação de identificação da personagem principal com a figura de um cego.
\end{abstract}

Palavras-chave: Lei; Exceção; Sujeito; Alteridade; Visão; Cegueira

\begin{abstract}
In “Amor”, a short-story by the Brazilian writer Clarice Lispector, our paper reads the way life and writing intersect, as different modalities of an encounter with the Other, suspending the limits between law and exception, knowledge and otherness, fact and fiction. Its premise is a state of blindness conceived not only as an experience of abandonment and insularity, of a sepulchral livin, - often described in the Western literary tradition: "myself my sepulchre, a moving grave, buried...", says John Milton, in Samson Agonistes... - but also, as in the case of "Amor", of an otherness and transcendance which suppose the impossibility of a clear distinction, and are also proper of all imaginary relationship. In Água Viva, that state of blindness expresses itself in a "figuration of the unnamable". In "Amor" it is presented by the allegorical figure of a blind man the main character identifies with.
\end{abstract}

Keywords: Law; Exception; Subject; Alterity; Vision; Blindness

Em “Amor" - conto de Clarice Lispector em Laços de família - as fronteiras entre o sujeito e o real vacilam. Um entra pelo outro adentro, para nele incorporar um exterior que de si mesmo o descentra. Movimento de dupla inscrição pelo qual se instaura, por um lado, no sujeito, uma certa alteridade pré-originária e, por outro lado, se desloca o mundo da sua própria autoconsistência, assim o subtraindo a qualquer visibilidade própria. Nos seus respetivos desdobramento interno e relativa (in)decisão limítrofe, não é apenas a visão que - condicionada por uma certa ficção que a cega... - de si mesma se desfasa. É também a lei que, na exceção em que tais limites se suspendem, se vê deslocada pela interrogação ontológica que eles trazem consigo. Poder-se-ia então dizer - como o fará Hélène Cixous, em "Saber ver", texto em que se cruzam a autobiografia, a ficção e a reflexão teórica que "ver era [então] um crer vacilante. Tudo era talvez. Viver estava em estado de alerta. [...] Ser e não ser não se excluíam mais" (2001, p. 9-12). E porquê? Porque haveria, então:

\begin{abstract}
Miopia mestra de erro e de inquietude. Mas ela reina também sobre outrem, sobre vós que não sois míopes e sobre vós que o sois, também a vós ela apanha, vós que nunca a vistes, que nunca soubésteis que ela estendia os seus véus ambíguos entre a mulher e vós. Ela estava ali a invisível que separava para sempre a mulher. Como se fosse o próprio génio da separação. Esta mulher era uma outra e vós não o sabíeis. [...] O que os videntes nunca viram: a presença-antes-do-mundo. Mas 'antes', não sabendo ela que via isso, vê-lo-ia? Os videntes, saberão eles que vêem? E os não-videntes, saberão eles que vêem diferentemente? Os olhos, verão eles que vêem? (Ibidem, p. 12-16)
\end{abstract}

Em "Amor", contudo, a esta "miopia" corresponde uma certa "cegueira", uma determinada figura de cego, também presente em outros lugares da sua obra. Em Água 
viva, por exemplo, a referência a essa cegueira resultaria em fórmulas como esta:

Estou me criando. E andar na escuridão completa à procura de nós mesmos é o que fazemos. [...] Atrás do pensamento atinjo um estado. [...] Perco a identidade do mundo em mim e existo sem garantias. Realizo o irrealizável mas o irrealizável eu vivo e o significado de mim e do mundo e de ti não é evidente. [...] Minhas raízes estão nas trevas divinas. Raízes sonolentas. Vacilando nas escuridões. [...] Minha história é de uma escuridão tranquila, de raiz adormecida na sua força, de odor que não tem perfume. E em nada disso existe o abstrato. É o figurativo do inominável. (LISPECTOR, 1980, p. 72-73, 82; sublinhados nossos)

A cegueira é, aqui, o correlato de uma perda de identidade do mundo. Se "em nada disso existe o abstrato" e se "existo sem garantias" é porque o que se vive não é o que acede à evidência, mas antes o que lhe escapa: "hoje é noite de muita estrela no céu. Parou de chover. Eu estou cega. Abro bem os olhos e apenas vejo" (ibidem, p. 86; sublinhado nosso). É portanto na "escuridão completa" ali onde nos buscamos a "nós mesmos"... - no entre-dois desse "figurativo do inominável", que se transpõem os limites do "realizável". É, então, que "o significado" do mundo recua e se perde da sua presença plena: se afasta da sua "identidade em mim". E das sonolentas "raízes" desta voz - que pertencem às "trevas divinas" e que, ao mesmo tempo, "vacilam nas escuridões" - se expande essa espécie de cegueira criadora:

Um mundo fantástico me rodeia e me é. [...] Exorbitome então para ser. Sou em transe. Penetro no ar circundante. Que febre: não consigo parar de viver. [...] Eis que de repente vejo que não sei nada. O gume da minha faca está ficando cego? Parece-me que o mais provável é que não entendo porque o que vejo agora é difícil: estou sorrateiramente entrando em contacto com uma realidade nova para mim e que ainda não tem pensamentos correspondentes, e muito menos ainda alguma palavra que a signifique. É mais uma sensação atrás do pensamento. (Ibidem, p. 68-70; grifos nossos)

Este encontro com o outro é, pois, a perder de vista... Ele pressupõe a sensação "atrás do pensamento". E o silêncio que, portanto, lhe corresponde. Ou ainda, como nos diria Emmanuel Lévinas, em "Linguagem e proximidade": "o visível acaricia o olho. Vê-se e entendese como se toca" (1997, p. 278). Ver não é, portanto, o exercício de uma distância, mas o limite de todo o limite. É, em suma, nesse encontro com o outro que, em Clarice Lispector, o que aqui designamos por alteridade préoriginária se afirma: "eu me ultrapasso abdicando de meu nome, e então sou o mundo" (1980, p. 49). "A impressão é que se não vou mais até às coisas é para não me deixar ultrapassar" (ibidem, p. 34). Dir-nos-ia Hélène Cixous:

Elle est allée hors frontières, où le moi n'est moi que comme pensée du monde et le monde n'est monde qu'à l'exception brillante du moi. [...] Elle a eu les deux courages: celui d'aller aux sources - à l'étranger du moi. Celui de revenir, à elle, presque sans moi, sans renier l'aller. Elle s'est glissée hors du moi, elle a eu cette sévérité, cette patience violente, elle est sortie par décollement, par rayonnement, par dépouillement des sens, il faut dévêtir la vue, jusqu'à la vue nue, il faut ôter des yeux les regards qui demandent, comme des larmes, dé-regarder jusqu'à la vue sans projet, la contemplation. (CIXOUS, 1989, p. 27-29)

O que se passará, então, em “Amor”?

\section{Uma estranha "doença da vida" ...}

É “Ana”, o nome da personagem que aqui nos chega, num confronto que, consigo mesma, a projetará na forma especular do seu duplo... Ela nos surgirá, então, na iminência de uma dispersão que - em torno da voragem de um certo vazio, de um certo informe... - se diria potenciada pela fragilidade da sua ligação com o mundo. E do primeiro dos seus perfis resultaria já, com efeito, um primeiro sinal: o de "uma estranha doença da vida", associada à sua juventude...

No fundo, Ana sempre tivera necessidade de sentir a raiz firme das coisas. E isso um lar perplexamente lhe dera. Por caminhos tortos, viera a cair num destino de mulher, com a surpresa de nele caber como se o tivesse inventado. $\mathrm{O}$ homem com quem casara era um homem verdadeiro, os filhos que tivera eram filhos verdadeiros. Sua juventude anterior parecia-lhe estranha como uma doença da vida. (LISPECTOR, s.d.: p. 18; grifos nossos)

A passagem do passado ao presente supõe já a dimensão de um certo inantecipável: "perplexamente, [...] por caminhos tortos", ela cai num "destino de mulher". A surpresa de vir a caber nesse destino "como se o tivesse inventado" abre, aí, para uma insuturável cisão do sujeito. Entre a exterioridade que a surpresa supõe e a interioridade da sua coimplicação, na suscitação desse destino... Margem de incalculável que nos lembra, em Água Viva, passagens como esta:

Tenho um pouco de medo: medo ainda de me entregar pois o próximo instante é desconhecido. $O$ próximo instante é feito por mim? Ou se faz sozinho? Fazemo-los juntos com a respiração. [...] Quando ao 
imprevisível - a próxima frase me é imprevisível. No âmago onde estou, no âmago do É, não faço perguntas. Porque quando é - é. Sou limitada apenas pela minha identidade. Eu, entidade elástica e separada de outros corpos. (LISPECTOR, 1980, p. 9, 28; grifos nossos)

Essa queda nesta "minha identidade" - que aqui me limita - é, simultaneamente, uma urdidura que, apesar de supor o meu protagonismo, me permanece exterior. Precisamente por supor um espaço de vacilação do limite entre dentro e fora é que ela não se enuncia, em "Amor", sem uma sua irónica inscrição no registo da ficção: naquele "como se" da sua invenção... A queda é, portanto, um movimento complexo. Cair num "destino" é também emergir de um estado de indeterminação: cai-se para cima e para fora de uma noite inicial. Como se, nessa anterior e inadvertida cegueira pressuposta pela queda - nessa espécie de invisibilidade do mundo do qual se emerge... - fosse ainda preciso inscrever a sua coautoria em alguma espécie de obscura sobrevisão:

Dela [dessa sua anterior juventude, estranha como uma doença de vida, Ana] havia aos poucos emergido para descobrir que também sem a felicidade se vivia: abolindo-a, encontrara uma legião de pessoas, antes invisiveis, que viviam como quem trabalha - com persistência, continuidade, alegria. O que sucedera a Ana antes de ter o lar estava para sempre fora de seu alcance: uma exaltação perturbada que tantas vezes se confundia com uma felicidade insuportável. Criara em troca algo enfim compreensível, uma vida de adulto. Assim ela o quisera e escolhera. (LISPECTOR, s.d.: grifo nosso)

Ana emerge, todavia, não apenas de uma certa ausência da visão - bem como de uma certa invisibilidade - mas também de uma certa privação do nome, um certo silêncio. Ora, o acesso ao simbólico faz-se, na construção do sujeito, pela injunção do nome. A dobra de uma certa (com)pulsão - de um certo "X", de um certo “it” (LISPECTOR, 1980, p. 81) - o inscreverá, então, como lei... Simplesmente - a lei é subtrativa. Ela oblitera, pela imposição do nome, a singularidade do "objeto" libidinalmente investido; interrompe - adia e desloca o vínculo do desejo, na instância do objeto nomeado... Como nos diria Jacques Lacan:

Le complexe d'Oedipe veut dire que la rélation imaginaire, conflictuelle, incestueuse même, est vouée au conflit et à la ruine. Pour que l'être humain puisse établir la rélation la plus naturelle, celle du mâle à la femelle, il faut qu'intervient un tiers, qui soit l'image de quelque chose de reussi, le modèle d'une harmonie. Ce n'est pas assez dire - il y faut une loi, une chaîne, une ordre symbolique, l'intervention de l'ordre de la parole, c'est-à-dire du père. Non pas le père naturel, mais de ce qui s'appelle le père. L'ordre qui empêche la collision et l'éclatement de la situation dans l'ensemble est fondé sur l'existence de ce nom du père. J'insiste - l'ordre symbolique doit être conçu comme quelque chose de superposé, et sans quoi il n'y aurait pas de vie animale possible pour ce sujet biscornu, qu'est l'homme. (LACAN, 1981, p. 111)

É, portanto, por intermédio do simbólico que todo o corte separador se opera. O que abre o objeto investido à possibilidade da circulação - da significação - é também que o retira da sua imediatez: a lei sob a forma da injunção do nome. Mas é o facto de a ordem simbólica ser "qualquer coisa de sobreposto" - qualquer coisa que "ultrapassa a existência vital"... - que, nesse nome, nos antecipa a presença da morte:

Il faut déjà pour cela qu'ait été instauré tout un ordre symbolique, qui comporte que le fait qu'un Monsieur Untel dans l'ordre social nécessite qu'on l'indique sur la pierre des tombes. Le fait qu'il s'est appellé Untel dépasse en soi son existence vitale. Cela ne suppose nulle croyance à l'immortalité de l'âme, mais simplement que son nom n'a rien à faire avec son existence vivante, la dépasse et se perpétue au-delà. (Ibidem)

É precisamente aqui - entre o imaginário e o simbólico, entre a vida e a morte - que se situará o que, em "Amor", de fundamental se joga... E porquê?

\subsection{A ficção do "real": um "destino de mulher"}

Porque o acesso ao simbólico aí nos coloca já num certo registo da ficção. Com efeito, nem o seu "destino de mulher", nem o da existência daquela "legião de pessoas [que], antes invisíveis", "viviam como quem trabalha com persistência, continuidade, alegria" - lhe escapam... O que é então que aí - nessa ficção do seu destino... - em Ana se deixa de lado? Um dos ensaios de Hélène Cixous - "Sunday, before falling asleep. A primal scene" - nos aproximaria de uma resposta:

Of course there is the trap 'man' and the trap 'woman'. Those are denominations in language and on identity cards. They are only social indicatives, part of our role playing. In every individual there is a whole complex play of femininity, of masculinity. [...] One evaluates with the look. It procedes through narcisism. [...] What gives, establishes value? We are going to see now all the system of symbolic value. [...] We are in a system of mirrors, [...]. The family looks on. [...] One has entered the world of shadows that does not exist. The little girl makes the apprenticeship of the shadows. (CIXOUS, 1990, p. 4-9; grifos nossos) 
Intuição que poderíamos, no entanto, encontrar também formulada em Água viva:

Terei de morrer de novo para de novo nascer? Aceito. Vou voltar para o desconhecido de mim mesma e quando nascer falarei de 'ele' ou 'ela'. Por enquanto o que me sustenta é o 'aquilo' que é um 'it'. Criar de si próprio um ser é muito grave. Estou me criando. E andar na escuridão completa à procura de nós mesmos é o que fazemos. Dói. Mas é dor de parto: nasce uma coisa que é. É-se. É duro como uma pedra seca. Mas o âmago é it mole e vivo, perecível, periclitante. Vida de matéria elementar. (LISPECTOR, 1980, p. 46; grifos nossos)

O "ser" é portanto apenas a forma endurecida, mineralizada da camada exterior de uma existência ao mesmo tempo perecível, periclitante. Cair num "destino de mulher" significaria, assim, endurecer: entrar na lógica da coerção exercida por este "sistema de espelhos" que a família é: the family looks on. A família e, para além dela, aquela legião de pessoas antes invisíveis. Mas significaria também perder o contacto com esse âmago do ser em que as transformações se marcam. Entrar, em suma, num mundo em que as sombras se multiplicam e a força injuntiva dos espectros intervém. Expor-se ao campo de forças no qual o simbólico se sobrepõe... "No fundo, Ana sempre tivera necessidade de sentir a raiz firme das coisas. [...] Criara em troca algo enfim compreensível, uma vida de adulto. Assim ela o quisera e escolhera" (LISPECTOR, s.d., p. 18).

No entanto, o passado de "antes de ter o lar", afastarse-ia ele definitivamente dessa sua "vida de adulto"? O movimento da queda, não transmitirá ele as condições que, na sua "juventude", o teriam já determinado? Diz-nos Jacques Derrida, em Memórias de Cego:

Pecado, falta ou erro, a queda significa também que a cegueira viola aquilo que se pode chamar aqui a Natureza. É um acidente que interrompe o curso das coisas ou transgride as leis naturais. E deixa pensar, por vezes, que o mal afecta, ao mesmo tempo que a Natureza, uma natureza da vontade - a vontade de saber [savoir] como vontade de ver [voir]. Uma má vontade teria levado o homem a fechar a si mesmo os olhos. O cego não quer saber ou antes gostaria de não saber [voudrait ne pas savoir]: Idein, eidos, idea: toda a história, toda a semântica da ideia europeia, na sua genealogia grega, sabemo-lo, vemo-lo, consigna o ver ao saber. (DERRIDA, 2010, p. 20)

A queda indiciaria, portanto, uma certa cegueira. Em “Amor", contudo, ela não é - ao menos literalmente uma privação dos olhos. Releva, antes, do que Derrida, mais adiante, designará por uma certa abocularidade (de ab oculis, na origem de "aveugle"). Poderíamos discernila aí: numa "certa má-vontade teria levado o homem a fechar a si mesmo os olhos". O que implicaria, portanto - naquela "estranha doença da vida" da "juventude" de Ana - um certo não querer saber... Uma certa "violação das leis naturais"? Sim, também: na medida em que "a natureza" - ou o que se entenda como "o curso natural das coisas"... - se baliza a partir da "cultura". Ou ainda: na medida em que é impossível defini-la senão com base nessa fiç̧ão sócio-histórico-ontológica que todo o simbólico pressupõe já... Hélène Cixous:

But as poets know and keep repeating, the law holds only to its name and by its name. [...] Elsewhere I have said that the system that puts a keeper before the law, the secret of which life (the secret of which is that there is no secret), is symbolized perfectly in the scene where there is a sentence, like a legend or a vignette, a sign in front of the biblical apple that says: "Thou shalt not enter". That is the other side of the law. But if we do touch, we will discover that the apple has an inside and that it tastes good. [...] That is the path I take in my reading of Água Viva. I could have taken it in any other text by Clarice Lispector. She says the same thing everywhere. The question of the law comes up everywhere. (CIXOUS, 1990, p. 11-12; grifo nosso)

O que se verificará, também, em “Amor". Mas - se o que aí se alcança, logo na sua abertura, é o chão de "uma vida de adulto", "a raiz firme das coisas": um "destino de mulher" - como é, mais exactamente, que a cegueira e a lei se cruzam? É que, entre o passado e o presente de Ana, essa cegueira que a queda indicia se reinscreve, por outro lado, como Forma. Cair num destino é tropeçar no confinamen-to, na estreiteza do visível. A ser assim, no entanto, por onde se deveria então fazer passar a fronteira entre passado e presente de Ana? Como distinguir aí entre invisível e visível? Ou isentar aí a norma de uma excepção a que ela se deveria opor? Como encontrar, então, o limite entre o movimento da linha que então se traça e a figura desse destino em que ela, finalmente, se fecha e detém? De novo Derrida:

Eis uma primeira hipótese: o desenho é cego, senão mesmo o desenhador ou a desenhadora. Enquanto tal e no seu momento próprio, a operação do desenho teria qualquer coisa a ver com a cegueira [aveuglement]. Nesta hipótese abocular (aveugle vem de ab oculis), não tanto a partir ou pelos olhos mas sem olhos), há que entender isto: o cego pode ser um vidente, tem por vezes vocação de visionário. (DERRIDA, 2010, p. 10-11)

Movimento que poderíamos reencontrar em Clarice Lispector: 
Estou consciente de que tudo o que sei não posso dizer, só sei pintando ou pronunciando, sílabas cegas de sentido. [...] Não sei o que estou escrevendo: sou obscura para mim mesma. [...] Tenho uma voz. Assim como me lanço no traço de meu desenho, este é um exercício de vida sem planejamento. $\mathrm{O}$ mundo não tem ordem visível e eu só tenho a ordem da respiração. Deixo-me acontecer. (LISPECTOR, 1980, p. 11, 24; grifos nossos)

E se "o desenho" se constituisse, portanto, como o referente alegórico do movimento pelo qual, em "Amor", Ana "se deixa acontecer"? Provinda daquela "estranha doença da vida" da sua juventude, uma certa des-lookação - um certo não querer saber, fechando a si mesma os olhos... - nela abriria espaço a uma espécie de enxertia, à inscrição suplementar de um olhar do outro a que, naquela "legião de pessoas, antes invisíveis", ela se expõe agora. O movimento da queda implicaria, então, a necessidade de uma outra "hipótese da vista": a de uma visão com outrem...

Segunda hipótese, enxertia do olho, enxertia de um ponto de vista [greffe d'un point de vue sur l'autre] no outro. Um desenho de cego é um desenho de cego. Duplo genitivo. Não há aqui nenhuma tautologia mas uma fatalidade do auto-retrato. De cada vez que um desenhador se deixa fascinar pelo cego, de cada vez que ele faz do cego um tema do seu desenho, projecta, sonha ou alucina uma figura do desenhador ou, mais precisamente por vezes, de alguma potência desenhadora. (DERRIDA, 2010, p. 10)

Uma certa transitividade suspenderia aí qualquer diferença pretensamente estanque. Entre o fechar a si mesmo os olhos e a enxertia pela qual o olhar cindido se desloca de si mesmo, se vislumbraria uma trémula passagem. Estas "hipóteses da vista" cruzam-se, diznos Derrida, "sem jamais se confirmarem uma à outra, sem a menor certeza, numa conjectura ao mesmo tempo singular e geral" (ibidem, p. 9). O que aí se joga é toda "a hipótese da vista, nem mais nem menos" (ibidem). Cruzá-las significa, portanto, a necessidade de pensar que todo o ver é "com" outrem... Sê-lo-ia já e, desde sempre, em qualquer sua articulação com o saber.... Não há, com efeito, visão pura. Nenhuma visão plena, ou qualquer espécie de imaculada perceção... Se o olhar supõe a presença do outro, é já na diferença consigo que esse outro intervém.

\subsection{A hipótese da vista: a questão da lei...}

Emergindo de um certo $a b$ oculis, a visão a que Ana acede confina-a à estreiteza do visível, às limitações de todo o "point de vue", às prescrições de toda a enxertia. Um certo a perder de vista se investiria, então, na instância do nome ou do simbólico. E, com ele, a injunção de um infindável recuo, diante de todo o presente pleno, induzido pelos registos do "como se" - ou do "como quem" - nos quais uma ficção real intervém. O que se passa, agora, na vida de Ana? Que sinais haveria, dessa outra espécie de cegueira?

Os filhos de Ana eram bons, uma coisa verdadeira e sumarenta. Cresciam, tomavam banho, exigiam para si, malcriados, instantes cada vez mais completos. A cozinha era enfim espaçosa, o fogão enguiçado dava estouros. $\mathrm{O}$ calor era forte no apartamento que estavam aos poucos pagando. Mas o vento batendo nas cortinas que ela mesma cortara lembrava-lhe que se quisesse podia parar e enxugar a testa, olhando o calmo horizonte. (Ibidem, p. 17; grifo nosso)

O que Ana nunca fará... Na sua recusa da contemplação desse calmo horizonte - desse horizonte velado: situado para além das "cortinas que ela mesma cortara"... - não será já o seu espectral pressentimento da presença desse inominado que aí atua? Aquela privação do nome que, no seu "destino de mulher", ela supusera, afinal, "para sempre fora do seu alcance"? Se, abolindo a felicidade, ela "encontrara uma legião de pessoas, antes invisíveis" que "viviam como quem trabalha" é já essa dimensão do "como se" - ou do "como quem" - que aí induz uma inquietante margem de indecidibilidade. A sua entrada na articulação entre ver e saber dir-se-ia, assim, acompanhada por algum inquietante pré-sentido. $\mathrm{O}$ da intromis-são de um certo invisível que, tanto no ver quanto no saber, então, se deveria reinscrever... Mantendo-se afastado desse "calmo horizonte", o seu olhar dir-se-ia que evita - a fórmula é de Michel Foucault, em $O$ Pensamento do Exterior - um "exterior [que] nunca se entrega na sua essência" (2001, p. 25). Uma vez que: "o exterior da lei é tão inacessível que ao querermos vencêlo e penetrar nele somos votados [...] ao exterior desse próprio exterior" (ibidem, p. 33-34). Que deslocamento então se adivinharia já? Na sua diferença consigo, uma série de rastos o irão prenunciando. Por exemplo:

Como um lavrador. Ela plantara as sementes que tinha na mão, não outras, mas essas apenas. E cresciam árvores. Crescia sua rápida conversa com o cobrador da luz, crescia a água enchendo o tanque, cresciam seus filhos, crescia a mesa com comidas, o marido chegando com os jornais e sorrindo de fome, o canto importuno das empregadas do edifício. Ana dava a tudo, tranquilamente, sua mão pequena e forte, sua corrente de vida. (LISPECTOR, s.d., p. 17)

Ana estende as mãos para diante: avança-as para / no seu espaço vital. Fá-lo num gesto que veremos reinscrito, mais adiante, na figura de um cego: "o cego interrompera 
a mastigação e avançava as mãos inseguras, tentando inutilmente pegar o que acontecia" (LISPECTOR, p. 20). Gesto próprio de toda a cegueira - "os cegos são seres da queda, sempre a expressão daquilo que ameaça a ereção ou a postura de pé" (DERRIDA, 2010, p. 29) - todo o "auto-retrato":

O tema dos desenhos de cego é antes de mais a mão. Esta aventura [a sua] precipita-se, é certo, mas desta vez nas vezes da cabeça, como que para a preceder, prevenir e proteger. Parapeito. A antecipação protege da precipitação, adianta-se ao espaço para ser a primeira a agarrar, para se lançar para diante no movimento da preensão, do contacto e da apreensão: de pé, um cego explora às apalpadelas a extensão que deve reconhecer sem ainda a conhecer - e o que na verdade ele apreende é o precipício, a queda - e ter já franqueado alguma linha fatal, com a mão desprotegida ou armada (a unha, a bengala, o lápis). Se desenhar um cego é, em primeiro lugar, mostrar mãos, é dar assim a observar o que se desenha com a ajuda daquilo com que se desenha [...]. (Ibidem, p. 12)

Ora, Ana "planta" - como vimos - apenas as sementes que tem na mão, e não outras... E "plantar" supõe também abrir, inserir, inscrever. Tudo se diria procedente, nesse gesto, dessa energia de vida que lhe vem do passado - do tempo de "antes de ter o lar"... Energia que ela a tudo comunica, com a sua mão pequena e forte... Das linhas da sua mão crescem, então, "árvores" - surge, portanto, a defluente expansão das linhas com que se povoa, se organiza e estabiliza o seu espaço vital. O que nos faz adivinhar, na tranquilizante ancoragem trazida pelo seu destino de mulher, a subsistência de alguma íntima desordem. É isso, no harmónico e decorativo recorte dos dias, na sua tentativa de aperfeiçoamento e de embelezamento, que Ana vai tentando "suplantar":

[...] sentia-se mais sólida do que nunca, seu corpo engrossara um pouco e era de se ver o modo como cortava as blusas para os meninos, a grande tesoura dando estalidos na fazenda. Todo o seu desejo vagamente artístico encaminhara-se há muito no sentido de tornar os dias realizados e belos; com o tempo, o seu gosto pelo decorativo se desenvolvera e suplantara a intima desordem. Parecia ter descoberto que tudo era passível de aperfeiçoamento, a cada coisa se emprestaria uma aparência harmoniosa; $a$ vida podia ser feita pela mão do homem. (LISPECTOR, s.d., p. 18)

O movimento da "grande tesoura" com que, nas suas mãos - tal como na "mão do homem" - ela vai moldando, útil e decorativamente, as roupas e os dias reúne-se, assim, à sua recusa da contemplação daquele calmo horizonte que os cortinados vêm a recobrir... Ambos se impõem
- formas substitutas - àquele seu desejo "vagamente artístico" de outrora. O movimento do corte é, portanto, o de uma conformação: o de um cerceamento regulador. Mas a reversora potência de uma ameaçadora dissipação instala-se. E será na vertigem de um certo vazio, no silêncio e no mistério de um certo inominável, que tudo se desencadeará:

Certa hora da tarde era mais perigosa. Certa hora da tarde, em que as árvores que plantara se riam dela. Quando nada mais precisava da sua força, inquietava-se. [...] Sua precaução reduzia-se a tomar cuidado na hora perigosa da tarde, quando a casa estava vazia sem precisar mais dela, o sol alto, cada membro da família distribuído nas suas funções. (Ibidem)

Como se a contenção do seu olhar - ali confinado aos limites impostos pelos seus afazeres, pelo espaço doméstico ou pelo "sistema de espelhos" em que se move, agora, o olhar do seu corpo habitante - a tivesse por um lado, confirmado - à medida em que iam crescendo "árvores" - e, por outro lado, desmentido - sempre que as árvores se riam dela... E ela fosse movida pelo espanto que a ela regressa:

Olhando os móveis limpos, seu coração se apertava de espanto. Mas na sua vida não havia lugar para que sentisse ternura pelo seu espanto - ela o abafava com a mesma habilidade que as lides da casa lhe haviam transmitido. [...] Quanto a ela mesma, fazia obscuramente parte das raizes negras e suaves do mundo. E alimentava anonimamente a vida. Estava bom assim. Assim ela o quisera e escolhera. (Ibidem, p. 19)

Fazendo obscuramente parte das raízes negras e suaves do mundo dir-se-ia ser, ainda, de um inominado "mal de raiz" que se trata. Que implicações terá ele, na relação de Ana com o espaço da cidade? Como se inscrevem essas raízes, na diferença de Ana consigo mesma?

\section{O recomeço do mundo: a sua estranha música...}

É precisamente nessa "hora instável" que o inantecipável se desencadeia: Ana "saía então para fazer compras ou levar objectos para consertar, cuidando do lar e da família à revelia deles" (ibidem, p. 18; grifo nosso). No trajeto do bonde, é repentinamente colhida pela mais inquietante das visões:

Foi então que olhou para o homem parado no ponto. A diferença entre ele e os outros é que estava realmente parado. De pé, suas mãos mantinham-se avançadas. Era um cego. O que havia mais que fizesse Ana se 
aprumar de desconfiança? Alguma coisa intranquila estava sucedendo. Então ela viu: o cego mascava chicletes... Um homem cego mascava chicletes. Ana ainda teve tempo de pensar por um segundo que os irmãos viriam jantar - o coração batia-lhe violento, espaçado. Inclinada, olhava o cego profundamente, como se olha o que não nos vê. (Ibidem; grifos nossos)

Que teria, no entanto, o cego de perturbador? Em primeiro lugar, ele estava "realmente parado"... Não só no espaço, portanto - como todos os que ali aguardavam por transporte... - mas também no tempo. Como se, tendo escapado ao tempo, ele ali ressurgisse, aos olhos de Ana, como que vindo de outrora: de um tempo que ela supusera "para sempre fora do seu alcance". Não teria sido isso que ali a teria feito aprumar-se de desconfiança? Que há de insólito na intermitência do mordaz sorriso que alterna com a expressão ponderativa, abstratamente fita, da sua seriedade? Não será o caráter informe da matéria elástica da "goma"? A expressão "um (homem) cego mascava chicletes" repete-se... O que se implica aí, nessa matéria informe que, incessantemente, na sua boca de cego, se revolve e altera sem se fixar? O que impressiona Ana é que:

Ele mastigava goma na escuridão. Sem sofrimento, com os olhos abertos. O movimento da mastigação fazia-o parecer sorrir e de repente deixar de sorrir, sorrir e deixar de sorrir - como se ele a tivesse insultado, Ana olhava-o. E quem a visse teria a impressão de uma mulher com ódio. (Ibidem; grifos nossos)

Que "desconfiança" e que "ódio" - que insulto a atingem, ali, naquele coração que lhe "bate violento, espaçado", no peito? Que espécie de tumulto dela se apodera, diante desse cego que mastigava goma na escuridão? O que se implica, da impermanência e da incessante deformação da matéria elástica, nessa escuridão em que o cego permanece, sorrindo sem sofrimento? Pois não trocara ela a perturbada exaltação do seu "desejo vagamente artístico" - a "insuportável felicidade" outrora exigida pela estranha "doença da vida" da sua juventude? Não as substituira ela pelo acerto - e pela privação - pelo cerceamento regulador que o "destino de mulher" em que cai lhe impõe? Não as rejeitara ela pela harmonia e pelo aperfeiçoamento? Pelo cuidado e pela contenção que tentara imprimir, à sua recente "vida de adulto"? Eis o "insulto": o cego "mastigava goma na escuridão. Sem sofrimento, com os olhos abertos"... O que dele fazia um signo de resistência: uma espécie de inquietante desmentido. Que seria ele senão a mais perturbadora das objeções à sua do destino em que coubera "como se o tivesse inventado"? Que poderia significar ele senão a denúncia daquela ficção da sua "vida de adulto" - "ela assim o quisera e escolhera"... - da abdicação que lhe é imposta pelo mundo visível em que entra? Unheimlich, diria Freud:

Esse 'Unheimlich' não é, na realidade, algo [de] novo ou desconhecido, mas sim algo há muito familiar da vida psíquica, que apenas dela ficou arredado através do recalcamento. [...] Muitas pessoas seriam capazes de considerar que o ponto culminante do sentimento de algo ameaçadoramente estranho é imaginar ser enterrado vivo. (FREUD, 1994, p. 228-330)

A essa "fantasia assustadora", a tradição literária do Ocidente consagrara-a já como tema. Nela se assimilaria a cegueira à experiência da morte em vida: de um sepultamento vivo. A que se juntaria, também, a da insularidade e a da prisão: uma certa experiência do abandono. Lembra Derrida:

No que se poderia chamar a retórica da cegueira, esta [a do ‘emparedamento'] é uma das figuras típicas. A cega de Rilke [...] diz os seus 'olhos murados' (vermauerten Augen). Esses muros plúmbeos encerram na noite da cova (os fariseus cegos são 'sepulcros caiados' [blanchis], o Sansão de Milton apresenta-se como um morto-vivo, exilado da luz, enterrado em si mesmo num túmulo em andamento: 'Myself my sepulchre, a moving grave, burried...'), e enclausuram também por detrás dos muros de uma prisão. (DERRIDA, 2010, p. 47)

Ao que se acrescentaria, também, "o isolamento especular [que] apela então à insularidade da imagem ou ainda, para reflectir o 'abandono' do cego e a sua solidão enlutada, a imagem da ilha: Die Blinde. Ich bin von allem verlassen. Ich bin ein Insel" (ibidem): "Fui abandonada por todos./Sou uma ilha e só" - diz a cega de Rilke, na sua enlutada solidão. Ou Hélène Cixous, em "Saber ver":

Estava tudo perdido. Cada passo aumentava a desorientação. Ficou petreficada, priva-da da ajuda da sua estátua [a da praça, que agora deixara também de ver]. Viu-se parada no seio do invisível. Via por todo o lado este nada pálido sem limites, era como se por um passo em falso tivesse entrado viva na morte. $\mathrm{O}$ aqui nada durava, não havia ninguém. Ela presa, caída de pé na extensão insondável de um véu, e eis tudo quanto restava da cidade e do tempo. A catástrofe tinha-se produzido em silêncio. E agora quem era ela? (CIXOUS, 2001, p. 9)

Mas o cego de Clarice é diferente: ele sorri-como que acintosamente... Nenhuma enlutada solidão, nenhum sentimento de perda do mundo... Se ele sorri é "sem sofrimento". E se Ana "continuava a olhá-lo, cada vez mais inclinada [... e] uma expressão do rosto há muito não usada, ressurgia-lhe com dificuldade, ainda incerta, 
incompreensível" (LISPECTOR, s.d., p. 19), o que a fascinará então, nesse cego que, entre sério e sorridente, ali se diria pressenti-la? Um cego-"vidente", dotado de alguma secreta sobrevisão, que ali o anima ou ilumina? Porque sorri ele, no interior do seu muramento, da sua ilha, da sua sepultura viva? Que significa ter ele "os olhos abertos"?

\subsection{A suspensão da lei: “à tona da escuridão”...}

Não representará o cego já a suspeita de que alguma vertiginosa invisibilidade se inscreveria já, em todo o visível? Não seria ele, enfim, a presença dessa "estranha doença de vida", dessas raízes negras e suaves do mundo às quais ela pertence? Não suporá ele o mais extremo impudor de algum obsceno autodesnudamento? De que movimento se trataria aqui, na aparente hesitação entre homem e mulher, no transitivismo desta cena, no auge da tensão conflitiva que marca, então, a sua vida? A julgar pelo que nos diz Hélène Cixous - em "L'auteur en vérité", a propósito de A Hora da Estrela, e do seu ficcionado autor "Rodrigo S. M. (na verdade Clarice Lispector)" ele não seria absolutamente inédito. Observa ela:

\begin{abstract}
Pour arriver à parler au plus près de cette femme qu'elle n'est pas, que nous ne sommes pas, que je ne suis pas, et que probablement, [...] l'auteur a dû trouver par hasard dans la rue ce qu'elle ["Clarice Lispector"] a fait - à moins que ce ne soit pas "elle" - c'est être le plus autre possible d'elle même, et cela a donné cette chose absolument remarquable: le plus autre possible en ce cas, c'est passer au masculin, passer par homme. (CIXOUS, 1989, p. 129-130; grifo nosso)
\end{abstract}

Eis do que se trataria, então, em A Hora da Estrela: por um lado, de Macabéa. Quer dizer, de uma personagem que "é antes de tudo vida primária que respira, respira, respira" (LISPECTOR, 1988, p. 19): pois ela "reduziase a si" (ibidem, p. 6). "Uma jovem que nem pobreza enfeitada tem" e em cuja "pobreza de corpo e espírito $e u$ ["o autor, Rodrigo S. M. (na verdade Clarice Lispector)"] toco a santidade, eu que quero sentir o sopro do meu além. Para ser mais eu, pois tão pouco sou eu" (ibidem, p. 27; sublinhado nosso). Por outro lado, da posição enunciativa capaz de dela nos dar conta. O que impõe a Rodrigo S. M. um certo rigor: "não tenho piedade do meu personagem principal" (ibidem, p. 19). Pois é preciso evitar que qualquer espécie de piedade o eforme...

$\mathrm{O}$ que escrevo um outro escritor escreveria. Um outro escritor, sim, mas teria que ser homem porque escritora mulher pode lacrimejar piegas. [Mas] eu não inventei essa moça. Ela forçou de dentro de mim a sua exigência. [...] Só eu a amo. (Ibidem, p. 19, 11)
Macabéa é, portanto, uma espécie de ausência, de quase transparente limiar: "Ela era quase impessoal, [... na] sua feiúra e anonimato total pois ela não é para ninguém [...]: não tinha consciência de si e não reclamava de nada, até pensava que era feliz" (ibidem, p. 25, 28).

Razão pela qual - observaria Hélène Cixous:

Moi 'Rodrigo S. M.' je suis en vérité Clarice Lispector mise entre parenthèses, et seule l'auteur “(en vérité Clarice Lispector)" peut s'approcher de ce commencement de femme. Cela est l'impossible vérité. C'est l'indicible, l'indémontrable vérité [...]. (CIXOUS, 1989, p. 134)

Porquê impossível, indizível e indemonstrável? Porque não poderia nunca haver, desse transitivismo, qualquer espécie de prova de existência:

C'est la vérité, une femme bat comme un coeur, dans la parentèse de la vie. Et c'est en ce point de douane où palpite indiciblement l'identité du je qui ne peut répondre, que le monde humain se sépare en deux camps. Ou vous comprenez cela, ou vous ne le comprenez pas. [...] On ne peut donner une preuve de l'existence de ce qui est plus vrai. Le truc est de croire. Croire en pleurant [...] et à ce moment-là on peut habiter le monde où l'être feminin et l'être masculin se côtoient, s'echangent, se caressent, se respectent, sont bien incapables de tenir le discours de la description exacte des différences, [...]. (Ibidem, p. 134-135; grifo nosso)

E porquê, uma vez mais? "Porque há masculino e há feminino num e noutro" (ibidem, p. 135). Essa ideia reforça-se em Jours de l'an. Com um elemento adicional: o da cegueira.

Qu'est que je vais devenir? L'auteur baissait. De moins en moins de lumière, de moi: d'elle, de lui? Plus personne ne pouvait le dire. Non, ce n'est pas facile d'écrire quand la personne que l'on invite nous est extrêmement étrangère. [...] Pour se mettre à la basseur de Macabéa, Clarice Lispector avait dû se dépouiller presque jusqu'aux os - la barbe, les ongles, le souffle, de vieux vêtements déchirés, c'est tout. Et la machine à écrire. Il ne voyait plus personne. Le personnage, l'auteur l'avait dans la peau [...]. (CIXOUS, 1990, p. 157; grifos nossos)

Relação de inscrição suplementar do outro... "Rodrigo S. M. (na verdade Clarice)" (LISPECTOR, 1988, p. 7) é, portanto, o seu outro. Mas um outro na instância de um certo imaginário, de um certo pré-simbólico já inscrito como exceção - como suspensão dos limites instaurados pelo simbólico: deslocadora ruptura da lei de qualquer diferença estanque: "a verdade é sempre um contato interior inexplicável. A minha vida mais verdadeira é 
irreconhecível, extremamente interior e não tem uma só palavra que a signifique" (ibidem, p. 17). De facto, se "eu também sou o escuro da noite" (ibidem, p. 24), a verdade é que "quando escrevo não minto" (ibidem, p. 25), "sigo uma oculta linha fatal. Sou obrigado a procurar uma verdade que me ultrapassa" (ibidem). E se "a pessoa de quem falarei [...] não faz falta a ninguém" (ibidem, p. 19-20) - "aliás - descubro eu agora - eu também não faço a menor falta" (ibidem: 20) - "tenho então que falar simples para captar a sua delicada e vaga existência" (ibidem, p. 21): "tenho de tornar nítido o que está quase apagado. Com mãos de dedos duros enlameados apalpar o invisível na própria lama" (ibidem, p. 25). Razão pela qual: "a ação desta história terá como resultado minha transfiguração em outrem e minha materialização enfim em objeto" (ibidem, p. 27), pois "apesar de eu não ter nada a ver com a moça, terei de me escrever todo através dela por entre espantos meus" (ibidem, p. 31). É isso que faz passar o silêncio e o escuro pela sua história: "juro que este é um livro feito sem palavras, [...] é um silêncio" (ibidem, p. 23): "a procura da palavra no escuro" (ibidem, p. 28). Porquê? Porque, quando a Macabéa: "ela é extremamente muda"... Se isto se verifica em A Hora da Estrela, o que se passa em "Amor"?

Em presença do cego, Ana dir-se-ia comparecer diante de si. Mas de um "si" anterior a si própria e a qualquer destino - o que seria indemonstrável: uma verdade impossível... E, nesse sentido, o cego com que ela se depara é também aquele outro cego de Rilke - de quem Derrida apenas nos cita apenas o exemplo de uma "cega"... Que nos diz então Rilke, em $O$ Cego?

Vede: Passa e interrompe a cidade, que deixa de existir no escuro em que ele está, como fenda escura passa pela alvura, duma chávena. E como numa folha

está pintado sobre ele o reflexo, das coisas, que não penetra nele. (QUINTELA, 1998, p. 135; grifos nossos)

Imune ao reflexo das coisas, o cego de Ana interrompe "a cidade". Não apenas a cidade, mas o seu destino de mulher. Masca pastilha elástica na escuri-dão, entre sério e sorridente: sem sofrimento... Suspende, em suma, toda a lei em que a cidade se sustenta. A começar pela do género. Uma lei a que o cego se diria, assim, permanecer cego e que, com ele, se diria deixar de existir, no escuro em que se está... O que dele emerge é já essa espécie de fenda escura que - passando, em Rilke, pela luminosa alvura da "chávena"... - aqui parece fender todo o signo... Essa fratura, que abre necessariamente para o espaçamento da linguagem, induz à suspensão da lei em que a cidade se sustenta. Contemplando-o, Ana dir-se-ia, assim, que a si mesma se descobre na insularidade e na sobrevivência do seu pleno abandono: "como que" sem olhos. O que por seu intermédio lhe chega é a ruína do visível, o espectro da (in)essência da polis. Uma fenda escura, agora, a atravessa: uma espécie de raiz escura. Traz consigo, no seu errático traçado, a inquietante intuição do que há de ficção em toda a lei. A insidiosa suspeita, não apenas quanto à inevitabilidade do espaçamento de toda a percepção, mas também quanto ao hiato que atravessa e cinde toda figura do destino... Que acontece então?

[Ela] continuava a olhá-lo, cada vez mais inclinada - o bonde deu uma arrancada súbita jogando-a desprevenida para trás, o pesado saco de tricot despencou-se do colo, ruiu no chão - Ana deu um grito, o condutor deu ordem de parada antes de saber do que se tratava - o bonde estacou, os passageiros olharam assustados. Incapaz de se mover para apanhar as suas compras, Ana se aprumava pálida. [...] O moleque dos jornais ria entregando-lhe o volume. Mas os ovos se haviam quebrado no embrulho de jornal. Gemas amarelas e viscosas pingavam entre os fios da rede. [...] E como uma estranha música, o mundo recomeçava ao redor. O mal estava feito. (LISPECTOR, s.d. p. 19-20; grifo nosso)

Eis, então, "o mal" por onde, afinal, o mundo incessantemente recomeça, como uma "estranha música": o informe da origem - a música enquanto mutação da forma em devir, fratura do futuro que de si mesmo se demarca. O mal de uma descontinuidade suspensa, de uma incompletude definitiva, de uma inapelável vacilação de todas as fronteiras. O mal na sua inicial viscosidade, simbolizada na goma que o cego mascava; o do exterior daquele calmo horizonte que o seu olhar prudentemente evitara. O mal, em suma, outrora velado pelas cortinas que, a própria Ana, com "a grande tesoura", cortara. O mal presente nas suaves raízes negras do mundo:

Perceber uma ausência de lei foi tão súbito que Ana se agarrou ao banco da frente, como se pudesse cair do bonde, como se as coisas pudessem ser revertidas com a mesma calma com que não o eram (Ibidem, p. 20).

Sem o simbólico - e sem, por conseguinte, o limite que ele pressupõe - o mundo perde a sua curvatura, o limite pertensamente uno e $n u$ da sua objectivação, a bainha do seu em-si-mesmamento, a possibilidade do seu conceito. Pois até:

O desejo é uma coisa que se articula. $O$ mundo no qual ele entra e progride, este baixo mundo, não é simplesmente um Umwelt no sentido de nele se poderem encontrar meios de saciar as necessidades, mas é um mundo onde impera a fala. [...] Nessa medida, a criança, que constitui sua mãe como sujeito 
com base na primeira simbolização, vê-se inteiramente submetida ao que podemos chamar, mas unicamente por antecipação, de lei. (LACAN, 1999, p. 194; grifo nosso)

Ora, em "Amor", com a arrancada do bonde:

A rede de tricot era [agora] áspera entre os dedos, não íntima como quando a tricotara. A rede perdera o sentido e estar num bonde era um fio partido; não sabia o que fazer com as compras ao colo. (LISPECTOR, s.d., p. 20)

Ou ainda... Reconhecendo-se na figura do cego e na "cegueira" que ele, ao mesmo tempo, representa e suspende... - Ana desprende-se então do que construira, ficcionalmente, não apenas o presente da sua vida real de adulto, mas também "a figura" do seu destino de mulher. E revê-se na sua própria "cegueira”. Olha-se de diante para trás: a perder de vista... Recua para si, nessa sua incursão pelo avesso de toda a visibilidade: até à escuridão que agora envolve, igualmente, toda aquela legião de seres que viviam como quem trabalha: "Parecia-lhe [agora] que as pessoas da rua eram periclitantes, que se mantinham por um mínimo equilíbrio, à tona da escuridão" (ibidem; grifo nosso).

Eis a verdade, portanto. Ou a sua impossibilidade:

Não havia como fugir. Os dias que ela forjara haviamse rompido na crosta e a água escapava. Estava diante da ostra. E não havia como não olhá-la. De que tinha vergonha? É que já não era mais piedade, não era só piedade: seu coração se enchera com a pior vontade de viver. Já não sabia se estava do lado do cego ou das espessas plantas. O homem pouco a pouco se distanciara e em tortura ela parecia ter passado para o lado dos que lhe haviam ferido os olhos. [...] Um cego me levou ao pior de mim mesma, pensou espantada. [...] Oh, mas ela amava o cego!, pensou, com os olhos molhados. No entanto, não era com este sentimento que se iria a uma igreja. (Ibidem, p. 24; grifos nossos)

Ei-la ciente, na sua insituabilidade, de fazer parte das obscuras forças que permanecem no limiar do mundo. No despertar daquela "estranha música" em que "o mundo recomeçava ao redor", nessa sua já intuída "ausência de lei" - "como se as coisas pudessem ser revertidas com a mesma calma com que o não eram" - a mão do cego é ainda um pouco da sua, como mão dada e guiada, e é na sua que essa mão avança também:

O cego interrompera a mastigação e avançava as mãos inseguras, tentando inutilmente pegar o que acontecia. [...] Um cego mascando chicletes mergulhara o mundo em escura sofreguidão. Em cada pessoa forte havia a ausência de piedade pelo cego e as pessoas assustavam-na com o vigor que possuíam. (Ibidem, p. 20; grifos nossos)
Apanhada por essa perigosa hora, na vertigem em que "através da piedade [agora] aparecia a Ana uma vida cheia de náusea doce, até à boca" (ibidem, p. 21) - como se nela, agora, a si mesma sentisse, no sabor da gema que verte dos ovos quebrados - ela perde a noção do seu ponto de paragem e, quando desce do autocarro... "Por um momento não conseguia orientar-se. Parecia ter saltado no meio da noite. Era uma rua comprida, com muros altos, amarelos" (ibidem; grifos nossos).

\subsection{Um "meio-sonho": o assassínio profundo...}

Esses "muros amarelos" - ela dar-se-á, por fim, conta de onde está... - cercam o Jardim Botânico. Onde ela entra e cuja...

[...] vastidão parecia acalmá-la, o silêncio regulava a sua respiração. Ela adormecia dentro de si. De longe ela via a aleia onde a tarde era clara e redonda. Mas a penumbra dos ramos cobria o atalho. [...] De onde vinha o meio-sonho pelo qual estava rodeada? (Ibidem, p. 21-22; grifos nossos)

O jardim botânico, cercado de muros amarelos é, na sua calma suave, não apenas a reduplicação da figura do ovo, mas também o silencioso espaço intramuros da reclusão que toda a cegueira supõe. $O$ espaço de uma "tranquilidade alta", de uma morte e de uma metamorfose sem mediação... O lugar de uma íntima desordem, uma insularidade e um abandono que supõem um certo sepultamento em vida no limiar de toda a alteridade:

As árvores eram pretas, doces como o mel. Havia no chão caroços secos cheios de circunvoluções, como pequenos cérebros apodrecidos [...] a crueza do mundo era tranquila. $\mathrm{O}$ assassinato era profundo. $\mathrm{E}$ a morte não era o que pensávamos. [...] A moral do jardim era outra. (Ibidem, p. 22; grifo nosso)

Qual seria, então, a moral do jardim? A moral da gema ou da goma, da sua secreta e íntima desordem, da exceção enfim? Que moral seria a do movediço mundo deste "Amor" cheio de piedade e, simultaneamente, de uma violência sem mediação?

Já não sabia se estava do lado do cego ou das espessas plantas. [...] O Jardim Botânico, tranquilo e alto, lhe revelava. Com horror descobrira que pertencia à parte forte do mundo - e que nome dar à sua misericórdia violenta? Seria obrigada a beijar o leproso, pois nunca seria apenas sua irmã. Um cego me revelou o pior de mim. Sentia-se banida porque nenhum pobre beberia água nas suas mãos ardentes. [...] Humilhada, sabia que o cego preferiria um amor mais pobre. E estremecendo, também sabia porquê. $A$ vida do jardim botânico chamava por ela como um lobisomem é chamado pelo luar. (Ibidem, p. 24; grifos nossos) 
Ora, como nos diz Giorgio Agamben, em $O$ Poder Soberano e a Vida Nua:

O que haveria de permanecer no inconsciente colectivo como um monstro híbrido, entre o humano e a fera, dividido entre a selva e a cidade - o lobisomem - é, portanto, na origem, a figura daquele que foi banido da comunidade. Que seja definido como homem-lobo e não simplesmente como lobo (a expressão caput lupinum tem a forma de um estatuto jurídico) é aqui decisivo. A vida do bandido - tal como a do homem sagrado - não é de natureza selvagem sem nenhuma relação com o direito e com a cidade; é, pelo contrário, um limiar de indiferença e de passagem entre o animal e o homem, a physis e o nomos, a exclusão e a inclusão: loup-garou, lobisomem, justamente, nem homem nem fera, que habita paradoxalmente em ambos os mundos sem pertencer a nenhum. (AGAMBEN, 1998, p. 103)

Eis, portanto, a sua "doença da vida" no limiar da lei: a de um certo inominável. Essa espécie de silenciosa metamorfose que a vida supõe: ali onde tudo se desenvolve e dissolve na geração e no letal abraço de um amor voraz e macio:

Ao mesmo tempo que imaginário - era um mundo de se comer com os dentes, um mundo de volumosas dálias e tulipas. Os troncos eram percorridos por parasitas folhudas, o abraço era macio, colado. (LISPECTOR, s.d., p. 22)

O jardim é, assim, o vertiginoso espaço da decomposição e da beleza, do nojo e da fascinação, da mais soberba impersonalidade e do mais terrível abandono. Mas também de uma certa alteridade préoriginária, de um pensamento do mundo sem o qual nenhuma subjetividade se poderia constituir... Espaço de exceção onde...

a decomposição era profunda, perfumada... Mas todas as pesadas coisas, ela via com a cabeça rodeada por um enxame de insectos, enviados pela vida mais fina do mundo [...]: o Jardim era tão bonito que ela teve medo do Inferno [...] (ibidem, p. 22-23) - Era fascinante, e ela sentia nojo [...], via o Jardim em torno de si, com uma impersonalidade soberba. (Ibidem, p. 23)

Tal seria a voragem onde todo o limite vacila: o lugar da repulsiva e fascinante "verdade", entre as duas conchas de uma ostra aberta:

Ela amava o mundo, tudo o que fora criado - amava com nojo. Do mesmo modo como sempre fora fascinada pelas ostras, com aquele vago sentimento de asco que a aproximação da verdade lhe provocava, avisando-a. (Ibidem)

Já de regresso a casa, "ao encontro do menino que se aproximou correndo" - ainda no transporte desse seu estranho êxtase: "por um instante a vida sadia que levava até agora pareceu-lhe um modo louco de viver" (ibidem). Nessa sua perturbada exaltação...

A piedade pelo cego era tão violenta como uma ânsia, mas o mundo lhe parecia seu, sujo, perecível, seu. [...] Como se soubesse de um mal - o cego ou o Jardim Botânico? - agarrava-se a ele [ao menino], a quem queria acima de tudo. Fora atingida pelo demónio da fé. A vida é horrível, disse-lhe baixo, faminta. (Ibidem)

Que diferença haveria, entre o cego e o Jardim botânico? Como se lê em Água viva:

Entro lentamente na escrita assim como já entrei na pintura. É um mundo emaranhado de cipós, sílabas, madressilvas, cores e palavras - limiar de entrada de ancestral caverna que é útero do mundo e dele vou nascer. [...] Para me refazer e te refazer volto ao meu estado de jardim e sombra, fresca realidade, mal existo e se existo é com delicado cuidado. Em redor da sombra faz calor de suor abundante. Estou viva. Mas sinto que ainda não alcancei os meus limites, fronteiras com o quê? Sem fronteiras, a aventura da liberdade perigosa. Mas arrisco, vivo arriscando. (LISPECTOR, 1980, p. 15, 18; grifos nossos)

Ora, uma mesma implicação se desdobraria, em "Amor":

A cidade estava adormecida e quente. $O$ que o cego desencadeara caberia nos seus dias? Quanto anos levaria a envelhecer de novo? Qualquer movimento seu e pisaria numa das crianças. Mas com uma maldade de amante, parecia aceitar que da flor saísse o mosquito, que as vitórias-régias boiassem no escuro lago. O cego pendia entre os frutos do jardim. [...] E se atravessara o amor e o inferno, penteava-se agora diante do espelho, por um instante sem nenhum mundo no coração. Antes de se deitar, como se apagasse uma vela, soprou a última flama do dia. (Ibidem, p. 25-26; grifos nossos)

Eis a sua perigosa hora; eis a sua "doença da vida": a de uma ausência de mundo... Onde caberiam elas? Não seriam elas também as nossas?

\section{Referências}

AGAMBEN, Giorgio. O poder soberano e a vida nua: homo sacer. Lisboa: Presença, 1998.

CIXOUS, Hélène. L'heure de Clarice Lispector. Paris: Des femmes, 1989.

CIXOUS, Hélène. Jours de l'an. Paris: Des femmes, 1990.

CIXOUS, Hélène. Reading with Clarice Lispector. Mineapolis: Minnesota University Press, 1990. 
CIXOUS, Hélène. Véus... à vela. Coimbra: Quarteto, 2001.

DERRIDA, Jacques. Memórias de cego: o auto-retrato e outras ruínas. Lisboa: Gulbenkian, 2010.

FOUCAULT, Michel. O pensamento do exterior. [s.1.] Fim de Século, 2001.

FREUD, Sigmund. Textos essenciais sobre literatura, arte e psicanálise. Lisboa: Europa-América,1994.

LACAN, Jacques. Le séminaire - III. Paris: Seuil, 1981

LACAN, Jacques. O Seminário - V: as formações do inconsciente. Rio de Janeiro: Jorge Zahar, 1999.

LÉVINAS, Emmanuel. Descobrindo a existência com Husserl e Heidegger. Lisboa: Instituto Piaget, 1997.
LISPECTOR, Clarice. Água viva. Rio de Janeiro: Nova Fronteira, 1980.

LISPECTOR, Clarice. A hora da estrela. Rio de Janeiro: Nova Fronteira, 1988.

LISPECTOR, Clarice. Laços de família. Lisboa: Relógio d'Água, [s.d.].

RILKE, Rainer Maria. O cego. QUINTELA, Paulo (Org.). Obras Completas III: traduções II. Lisboa: Gulbenkian, 1998.

Recebido: 20 de outubro de 2015 Aprovado: 18 de dezembro de 2015 Contato: jpper@ualg.pt 